\title{
BENCHMARKING OF THE PARADIGMS OF INNOVATION POLICY FORMATION: THE CONCEPTUALIZATION OF POSSIBLE BORROWING EXPERIENCE
}

\author{
Shostak L. B., Dikarev O. I.
}

\begin{abstract}
"rules of art can be useful but they do not determine the practice of an art; they are maxims, which can serve as a guide to an art only if they can be integrated into the practical knowledge of the art"
\end{abstract}

(Polanyi, 1962: 50)

\section{INTRODUCTION}

Benchmarking in this study dedicates examples of successful' practices process of adapting in foreign experience during shaping innovative policy. The concept of benchmarking was developed by McAdam R., Watson G., Kyro P., Davis P., Bogan C., et al. Benchmarking includes two matters: the continuity of the process and its structuredness. The concept of a national innovation system was introduced in the twentieth century and subsequently described by many experts. The earliest work in this sphere belongs to B.A. Lundvall, R. Nelson, C. Freeman, P. Patel, K. Pavitt.

It should be first of all noted that in the world there are more than 20 countries that are considered OECD as innovative and practice such policy. These are the states with the following features: 1) the country has organized the production of new knowledge and their transformation into innovations and new technologies; 2) an information infrastructure is created that allows the storage and dissemination of knowledge and innovation; 3) an organized demand process from the part of production for innovation in order to increase competitiveness; 4) the social structure of society leads to the spread of innovations in all spheres of life.

Secondly, we need to conceptualize that, despite the recent slowdown in global growth, innovations continues to be a crucial driver of the economy in developed and developing countries. It is the main source of investment in research, development and innovation (R\&D\&I), with 
manufacturing companies responsible for more than $85 \%$ of the R\&D carried out by the private sector in Germany, Japan and South Korea. Technology and innovation have been and will remain central to how production evolves and is transformed. Over the past 20 years, labor productivity across industries in the United States increased by $47 \%$, driven primarily by technology adoption and innovation. Society is at the juncture of the increasing convergence of production and consumption, which is mainly driven by new business models enabled by transformations in technology. In the context of the Fourth Industrial Revolution, production is at the cusp of a paradigm shift driven by three technological megatrends that have reached unprecedented pace and breadth, even as their full-scale adoption and benefits in production is yet to be realized ${ }^{1}$.

Third, we need to recognize concept of analysts:

1. Richard R. Nelson about that a national innovation system emerges from the belief that a nation's technological capabilities are its primary source of competitive performance and that these capabilities can be built through national action (Nelson 1993) ${ }^{2}$;

2. Philip E. Auerswald and Lewis M. Branscomb about that a nation's innovation system is shaped by how the nation leverages its endowmentsnatural resources, culture, history, geography, and demographics - through policies that create a thriving market-oriented (firm-centric) economy and accelerate the transition of new technologies, processes, and services to the market. The core of a nation's innovation system, then, are its endowments and how government and industry leverage these endowments - the nation's government through policy investments, incentives, regulations and industrial firms through strategies, investments, and training ${ }^{3}$.

Fourthly, it is necessary, when comparing, to consider the uncertainty factor highlighted by Richard R. Nelson that in spite of the fact that the core of the innovation economy, which is the national innovation system, was created in many developed countries of the world as early as the end of the 20th century, the theoretical construct of innovative economics has hitherto been used by many researchers as insufficiently defined concepts. There is,

\footnotetext{
${ }^{1}$ Zimmermann V. An international comparison of R\&D: Germany benefits from industrial research strength", KFW research, No. 105, 25 August 2015.

2 Richard R. Nelson. National Innovation Systems: A Comparative Analysis 1st Edition / Richard R. Nelson. Oxford University Press; 1 edition, 1993. 560 p.

${ }^{3}$ Auerswald Philip E. Valleys of Death and Darwinian Seas: Financing the Invention to Innovation Transition in the United States / Philip E. Auerswald and Lewis M. Branscomb. The Journal of Technology Transfer. August 2003, Volume 28, Issue 3-4, pp. 227-239.
} 
first of all, the concept to a national innovation system itself. Each of the terms can be interpreted in a variety of ways, and there is the question of whether, in a world where technology and business are increasingly transnational, the concept as a whole makes much sense. Consider the term "innovation", the participants, interpret the term rather broadly, to encompass the processes by which firms master and get into practice product designs and manufacturing processes that are new to them, whether or not they are new to the universe, or the nation. Richard R. Nelson does that for several reasons: 1) the activities, and investments associated with becoming the leader in the introduction of a new product or process, and those associated with staying near the head of the pack, or catching up, are much less sharply distinguishable than commonly is presumed; 2) much of the interest in innovative capability is tied to concern about economic performance, and here it is certainly the broader concept rather than the narrower one that matters. This means that our orientation is not limited to the behavior of firms at the world's technology forefront, or to institutions doing the most advanced scientific research, although in some countries the focus is here, but is more broadly on the factors influencing national technological capabilities. Then there is the term system. While to some the word connotes something that is consciously designed and built. Rather the concept here is of a set of institutions whose interactions determine the innovative performance, in the sense above, of national firms. There is no presumption that the system was, in some sense, consciously designed, or even that the set of institutions involved works together smoothly and coherently. Rather, the "systems" concept is that of a set of institutional actors that, together, play the major role in influencing innovative performance. The broad concept of innovation that we have adopted has forced us to consider much more than simply the actors doing research and development. Indeed, a problem with the broader definition of innovation is that it provides no sharp guide to just what should be included in the innovation system, and what can be left out ${ }^{4}$.

Fifth, it is necessary to take into account the factor of national peculiarities. Countries differ in their traditions, ideologies, and beliefs about appropriate roles for government, and they will guard the differences they think matter. A national innovation system also encompasses many

\footnotetext{
${ }^{4}$ Nelson Richard R. National Innovation Systems: A Retrospective on a Study. Industrial and Corporate Change. 1992 January, 1(2), 347-374.
} 
innovation "pipelines", which are strategies for advancing innovation to industrial output. Such strategies are not necessarily linear. These pipelines aim to create a healthy innovation ecosystem through functional policies that guide primary actors to foster innovation. National governments may have a range of motives for pursuing innovation. Chief among them is economic development to increase national wealth and prosperity via the creation of new products and services and, in turn, high-paying jobs. For high-wage countries like South Korea, this may mean having more attractive products or better production processes than firms in low-wage countries. In the economic reality of the post-Soviet countries, to date, there is a number of components without which it is impossible to imagine an efficiently functioning national economic innovation complex (such a complex, for example, already established and operating in the US): 1) in the opinion of the Belarusian economist, L.M Kryukov, "Today, none of the CEE and CIS countries have a scientific innovation system. But there is an active search for the most effective approaches to its creation. This problem is intensively being developed in Russia",5. However, at present "there is no reason to say that national innovation. The system in Russia has already been established, it remains to be completed. She is only at the beginning of the path" 6 . For its creation in the "Basic directions of the policy of the Russian Federation in the field of development of the innovation system for the period up to 2010" included the relevant activities, which are planned to be implemented within the next five years. However, the Russian researcher E. Semenov expresses reasonable doubt as to the specified time, fairly assuming that "to form a modern innovation system for this period of time, apparently, is unlikely" (B. Kuzyk, Yu. Yakovets, 2005, p. 26). For comparison, in the United States, such an innovative system was created over 50 years ${ }^{7}$.

In view of the absence in the modern economic practice of the postSoviet countries of the above-mentioned components, of which, in many respects, the innovative economy as a national economic system develops, many researchers in their works prefer to call the last "innovative sector of

\footnotetext{
5 Крюков Л.М. Национальная инновационная система: проблемы становления и развития. Белорусский экономический журнал. 2003. № 4. С. 66-75.

6 Кузык Б.Н., Яковец Ю.В. Россия-2050: стратегия инновационного прорыва. 2-е изд. Москва, 2005. $440 \mathrm{c}$.

${ }^{7}$ Иванова Н.И. Национальные инновационные системы. Москва, 2002. С. 86-87.
} 
the economy", which corresponds more to domestic economic realities. From other sectors of the domestic multi-layered, "multi-layered, multifunctional economy" ${ }^{\prime \prime}$ innovation sector is characterized by the fact that innovation is used as the main economic resource, while in the high-tech sector it is high technologies, in the financial sector, finance, etc. The conceptual block of questions associated with the development of an innovative economy is considerably better developed in the post-Soviet countries, the content of which allows us to consider it as a frontier scientific discipline, formed at the junction of economic science, innovation and science. An addition, a number of innovative models, which are abstract constructs that simplify the main features of the economic system of this type, have been created by specialists in innovative economics, innovation and science. So, in the opinion of the Belarusian economist M.V. Myasnikovich, "in the majority of them they are reduced to two: the economy of small and the economy of big money" ${ }^{\prime 10}$. One of the leading Ukrainian experts in the science of economics B.A. Malitsky considers that the initial frontier of the innovative model of economy can be spoken then, when the innovation described by its assistance to the national economic system reaches $40 \%{ }^{11}$. Finally, the authors of the monograph "Innovative Economic Development: Model, Management System, State Policy" (K., 2005), not only describe different models of innovative economic development, but also distinguish several types of innovative economy ${ }^{12}$. The analysis of the typological features of the domestic innovation economy allows V.K. Shcherbin to give it the following definition that is: 1) the emerging industrial relations of innovation character; 2) the national economy sector, which provides GDP growth through the commercialization of research and development; 3 ) border scientific discipline, formed at the junction of economic science, innovation and science ${ }^{13}$.

\footnotetext{
${ }^{8}$ Семиноженко В.П. Інноваційна політика України як національний проект. Економіка знань: виклики глобалізації та Украӥна / Під заг. ред. А.С. Гальчинського, С.В. Льовочкіна, В.П. Семиноженка. Київ, 2004. С. 18-39.

${ }^{9}$ Потемкин А. Виртуальная экономика. Москва, 2004. С. 27.

10 Мясникович М.В. Роль науки в инновационной деятельности Беларуси. Инновационная политика государства и пути ее реализащии : Материалы семинара. Мн., 2004. С. 81-96.

${ }^{11}$ Малицький Б.А. Перепони інноваційного розвитку економіки та шляхи їх подолання. Утвердження інноваційної моделі розвитку економіки Украӥни. Матер. наук.-практ. конф. Київ, 2003. С. 160-165.

${ }_{12}$ Інноваційний розвиток економіки: модель, система управління, державна політика / За ред. Л.І. Федулової. Київ, 2005. С. 31-32.

13 Щербин В.К. Типологические отличия инновационной экономики. URL: http://iee.org.ua/ files/alushta/66-scherbin-tipologi4eskie_otli4iya.pdf (18.01.2012).
} 


\section{Innovation' paradigm: what is this?}

A review of the literature on innovation and diffusion reveals several paradigms as to just what an innovation is:

1. Problem of technological innovations has not been considered a priority by the classic theorists. Due to the fact, no special importance is ascribed to the innovation development theory, in spite of the fact that Smith, Ricardo, Marks, Marshall, Keynes and Solow are almost unanimous, stating that long-term efficiency growth is inextricably related with introduction and diffusion of technological and organizational innovations;

2. One of the paradigms was developed by Everett Rogers. He defines innovation as "an idea, practice, or object that is perceived as new by an individual or other unit of adoption"14. For E. Rogers, innovations are singular inventions that are adopted via a process of protagonist "marketing". At issue is the potential adopters behavior (i.e. attitudes and personality) - rather than their ability to adopt, and the ability of the agent promoting the innovation to persuade the potential adopter;

3. In contrast to the Rogers's concept, H. Barnett (1953) ${ }^{15}$, B. Agarwal and others have argued that innovation and diffusion are not separate processes - that innovation is essentially the first step in the diffusion process - and those potential adopters decisions concerning adoption is based on rationality rather than persuasion ${ }^{16}$. In this paradigm, innovations are ideas or technologies which are continually adapted as they are adopted, and represent sequential sociocultural change. J. Schumpeter's simple definition that innovations are "the carrying out of new combinations" also fits this contrasting school of thought ${ }^{17}$;

4. So called Economists have focused on the economic factors "inducing" innovation, and have taken a market rather than personal perspective. Ruttan and Hayami (1984), utilize a functionalist, neoclassical argument that innovation results from the endogenous scarcity of some component of production ${ }^{18}$. The neo-classical school has been criticized by another group of economists that emphasize the importance of

\footnotetext{
${ }^{14}$ Rogers E. M. Diffusion of Innovations / Rogers E. M. - 3rd ed, The Free Press. - New York, NY, 1983. P. 11.

${ }^{15}$ Barnett, H.G. (1953). Innovation, the Basis for Cultural Change. New York: Mc Graw Hil.

${ }^{16}$ Barnett, H.G. (1953). Innovation, the Basis for Cultural Change. New York: Mc Graw Hil.

${ }^{17}$ Schumpeter J. The Theory of Economic Development / Schumpeter J. // Harvard University Press, Cambridge - 1934 .

${ }^{18}$ Ruttan, V.W. and Hayami, Y. (1984) Toward a Theory of Induced Institutional Innovation. Journal of Development Studies, 20, 203-223.
} 
exogenous, structural factors (history, international markets, politics and institutions) in "inducing" innovation (A. de Janvry 1985)

5. So called Anthropologists are divided largely between those who consider humans to be pragmatists with innovations a function of their rational objectives and characterized by the materials at hand, and those who consider humans meaning- and symbol-making beings with innovations a function of their subjectively defined beliefs. Two anthropologists, $\mathrm{H}$. Barnett and S. Gudeman, offer arguments that bridge this gap between the "induced" argument of the economists and the "culturalist" arguments of some anthropologists. At the personal level, the "induced" innovation model of Ruttan and Hayami would fit within Barnett's model ${ }^{20}$. Accepting the Barnett's and Schumpeter's definition of innovation - as that of making new combinations of familiar things $-\mathrm{S}$. Gudeman proposes that people create new things for use, and simultaneously create culture (Gudeman 1991). A discarded food bowl used for a chimney cap is thus both an innovation with practical use value and a cultural creation. This proposal is both a refinement and extension of the Barnett model.

Using the idea of a hierarchy of levels of innovation and working within the evolutionary approach, Geels (2002) put forward a multi-level perspective of how transitions to radically new technological systems could occur and how policy support (i.e. transition management) might this facilitate. This multi-level perspective is important for an understanding that breakthroughs of innovations are dependent on multiple processes in the wider contexts of regimes and landscapes.

According to Geels, transitions do not only involve changes in technology, but also changes in user practices, regulation, industrial networks (supply, production, and distribution), infrastructure, and symbolic meaning or culture. Geels uses three explanatory levels: technological niches at the micro level, sociotechnical regimes at the average level, and landscapes at the macro level, as first proposed by Kemp (1994). A sociotechnical regime reflects the interaction between the actors and institutions, and the resultant routines and practices, involved in creating and reinforcing a particular technological system (Winskel and Moran, 2008). These

\footnotetext{
${ }^{19}$ Alainde Janvry, Elisabeth Sadoule. A study in resistance to institutional change: The lost game of Latin American land reform. World Development. 1989. Volume 17, Issue 9, September. P. 1397-1407.

${ }^{20}$ Ruttan, V.W. and Hayami, Y. (1984). Toward a Theory of Induced Institutional Innovation. Journal of Development Studies, 20. P. 203-223.
} 
practices include: engineering practices; production process technologies; product characteristics, skills and procedures embedded in institutions and infrastructures (Foxon et al., 2010 [in press]). Thus, in so far as firms differ in their organizational and cognitive routines, then there is variety in the technological search directions of engineers. In so far as different firms share similar routines, this form a regime. Technological regimes produce technological trajectories, because the community of engineers searches in the same direction. Technological regimes thus create stability in the direction of technical development (Geels, 2002). This is closely related to the concepts of path dependency and lock-in.

Alongside the multiple-level perspective has emerged the proposal for "transitions management" and "strategic niche management" by governments in order to promote and protect the development and use of promising technologies (Fouquet, 2010). Strategic niche management differs from simple "technology push" policies, particularly in the role that states undertake (Maréchal, 2007). Echoing the multiple-level perspective, there is recognition that government and firms, as well as other stakeholders, have a central role to play in a system change and, for example, in the diffusion of low carbon technologies and that there is a need for policy-makers to manage the dynamics of possible transitions in order to avoid early lock-ins. According to Rennings et al. (2004), transition management is not so much about the use of specific economic instruments but more about different ways of interaction between entities, the mode of governance, and goal seeking. If innovation and learning are the aims of transition management then this requires a greater orientation towards outsiders, a commitment to change and clear stakes for regime actors.

Research under the transitions approach is to develop "socio-technical scenarios". Such a scenario "describes a potential transition not only in terms of developing technologies but also by exploring potential links between various options and by analyzing how these developments affect and are affected by the strategies (including policies) and behavior of various stakeholders" (Foxon et al., 2010 [In press]). Elaborating on the socio-technical scenarios method, Foxon et al. offers a theoretical approach to developing transition pathways. Three main steps to specifying transition pathways are identified: Characterize key elements of existing regime (socio-technical, actors, and landscape). Identify key processes that 
influence dynamics and stability, especially at the niche level. Specify interactions giving rise to or strongly influencing transition path ${ }^{21}$.

As a result of this diversity a number of studies have attempted to identify specific innovation determinants (e.g. Damanpour 1991, 1996; Wolfe 1994; Ravichandran 2000). In an impressive meta-review, Damanpour (1991) identified thirteen determinants of innovation: specialization, functional differentiation, professionalism, and formalization, and centralization, managerial attitude toward change, managerial tenure, technical knowledge resources, administrative intensity, slack resources, external communication, internal communication, and vertical integration. As such determinants still fail to yield consistent findings, researchers have introduced a number of moderating variables in order to tease out the different relationships and establish more stable and cumulative results. Examples of such moderators are organizational characteristics such as conservative and entrepreneurial (Miller and Friesen, 1982), mechanistic and organic (Burns and Stalker, 1961), traditional, mechanical, organic and mixed (Hull and Hage, 1982), manufacturing or service oriented (Mills and Marguiles, 1980), old or new (Koberg at al., 1996), big or small (Nord and Tucker/ 1987), prospecting, defending and analyzing strategy (Miles and Snow, 1978), and innovation characteristics in the form of administrative and technical (Daft, 1978), product and process (Utteback and Abernathy, 1975), appropriability regime and level of output (Klepper, 1996), incremental or architectural (Tidd, 1995), level of complexity (Rogers and Shoemaker, 1971). While Damanpour (1991) claims that some determinants of innovation may indeed be stable and cumulative once suitable moderators have been included, the generally poor track record of these research efforts is enough to warrant some reflection ${ }^{22}$.

\section{Types of innovation policy in developed countries}

According to the typology, the following types of innovation policy are distinguished:

1. Countries aimed at realizing the goals of sovereignty.

2. Countries aimed at diffusing technologies or spreading technologies in the industrial sector.

\footnotetext{
${ }^{21}$ Innovation Theory: A review of the literature ICEPT Working Paper May 2012.

${ }^{22}$ Berglund Henrik. Interesting Theories of Innovation: the Practical use of the Particular / Henrik Berglund. Department of Innovation Engineering and Management Chalmers University of technology. 2004. WP \# 2004:1, 22 p.
} 
3. Countries that catch up with the leaders of innovative development.

It should be noted that individual programs and projects of each country at different periods of development and priorities of innovation policy may be related to a different type of policy.

For example, in Germany, which belongs to the group of countries focused on the diffusion of technology, there are projects corresponding to the group of countries - "mission carriers" and aimed at goals of national importance. Separately, Japan should be singled out, which from the group of catching-up countries "broke free" into a complex of orientation towards diffusion of technologies and orientation towards goals of national importance.

Thus, it is advisable to consider the development of the innovation process in each of the most successful countries in more detail. The degree of penetration of innovation, technology in all areas of life in the United States is one of the highest in the world. For many years the United States has been a recognized leader in the innovation market, and the United States is the benchmark for the development of other countries in the field of innovation. However, in recent years, some countries are catching up and even ahead of the United States in some parameters of innovative development, such as patent activity, the concentration of researchers per million people, etc. Elements of the post-war national innovation system of the United States originated in the 1945-50s. The federal government played a large role in this process, supporting research and development not so much in public sector laboratories as in universities and the private sector $(71.1 \%)$. It was then that cooperation began between these three elements, which led to amazing results. Currently, the state, in cooperation and coordination with business and universities, is developing practical programs in the field of science and technology. The efficiency and prosperous state of the US innovation system is associated with fierce competition and the self-development of companies. The success of the American NIS is not only the exact formulation of development strategies and ideas, but also the organization of the innovation process. Scientific centers, laboratories within corporations, research centers, both state and universities, study, formulate innovative proposals that small companies then engage in. With regard to $R \& D$, there are three main elements of activity: universities, national laboratories, innovation clusters. Universities prepare specialists and are engaged in technological 
developments, national laboratories are engaged in government orders, and innovative clusters are "engaged" in high-tech production and research.

Separately, it is necessary to single out the Federal Contracting Centers, which are an example of cooperation between the state, universities and the private sector. The federal contract system has a strong influence on the innovation market through maintaining and creating government demand. We can distinguish two features inherent in federal contract centers: state funding and the organization's contract system. Federal contract centers are designed to solve problems in the field of R\&D (which are funded by the state) by combining the resources of laboratories and universities. Separately, it is necessary to allocate the main cluster in the United States - Silicon Valley. The creation of Silicon Valley is an example of both the cooperation of business, universities and the state, as well as an example of the creation of a leading innovation cluster. Attempts to recreate or copy the success of Silicon Valley by different countries at different sites do not lead to the expected results. No one managed to create "their" Silicon Valley. The reason for the success of the United States is the combination of individual characteristics that add up to the system: the US innovation policy, the developed venture market, the open labor market, and the interaction between business, research centers, and universities ${ }^{23}$.

Germany is proving that even a high-wage nation can compete globally in manufacturing. Exports of everything from kitchen equipment and industrial machinery to high-speed trains and wind turbines by small and large firms alike 296 surged by 18.5 percent in 2010 to $€ 951.9$ billion (\$1.3 trillion), leading the country out of recession. German net exports of goods contributed 1.4 percentage points to its 3.6 GDP growth in 2010, or 40 percent of the total increase. German exports to China soared by 44 percent, which could become Germany's biggest export destination overall by 2015 . Unemployment in Germany fell to an 18-year low in January 2011. Innovation and a system for efficiently converting new technologies into marketable products and large-scale production are keys to this success. Germany's innovation system is characterized by heavy corporate and government investment in research, innovative small- and mediumsized enterprises, extensive workforce training, and strong institutions such

\footnotetext{
${ }^{23}$ The U.S. National Innovation System: Recent Developments in Structure and Knowledge Flows David C. Mowery/ Haas School of Business, University of California, Berkeley and Canadian Institute for Advanced Research, 1996.
} 
as Fraunhofer-Gesellschaft that collaborate with Germany industry. The government also works to assure that the nation is a "lead market" for important, emerging technologies through methods such as consumer incentives, government procurement, and standards. Such policies have enabled Germany to become the world's leading exporter of researchintensive products, according to the German Institute for Industrial Research (DIW Berlin). More than 12 percent of Germany's exports are research-intensive that double the level of the US. Germany is a world leader in optics, a $€ 2$ billion industry that also has received significant public support. German machine tool makers are the world market leaders with a share of 19 percent. The nation has some 500 biotechnology companies, and the nanotechnology sector boasts 740 companies and 50,000 industrial jobs. Germany also ranks No. 4 in the world in patents granted. Over the past decade, the German government has implemented an ambitious agenda designed to maintain the strength of Germany's global competitiveness. Chancellor Angela Merkel's government has increased investments in $\mathrm{R} \& \mathrm{D}$, which raised by one-third to $€ 12$ billion (\$17.1 billion) from 2005 through 2008. Germany spent $€ 80$ billion in economic stimulus during the financial crisis, followed by a further $€ 11$ billion in stimulus that went to education and science and technology. The government also has been implementing a wide range of policies and programs to improve its innovation system. They include initiatives to upgrade basic science, boost private $R \& D$ spending, strengthen collaboration between universities and business, improve the environment for high-tech start-ups, and nurture regional innovation clusters. The government also has unveiled what it describes as Germany's first comprehensive national innovation framework, High-Tech Strategy 2020, which seeks to consolidate public programs around well-defined missions. German innovation still faces a number of serious challenges, however. They include a scarcity of venture capital and bank loans for innovative companies, declining momentum in sectors such as electronics and aircraft, and weak performance in eastern Germany and Berlin, which consume a large share of federal research spending but produce relatively little innovation. Germany ranks below most other industrialized nations in researchers as a percentage of total employment, measures of international collaboration in research, and venture capital as a percentage of GDP. There also are fears of a looming skills shortage due declining university 
enrollment as the population ages and disinterest in science and technology fields grows among German youth. The Expert Commission on Research and Innovation, known by its German acronym EFI, reports an "urgent need to expand education, research and innovation" and warns that Germany's global competitiveness is under threat. The EFI also contends that Germany's tax system must become more innovation-friendly.

Germany's innovation system differs from that of the US is several fundamental ways. While the US has an "entrepreneurial economy", Germany's model is more oriented toward "solid, high-quality progress". While labor and skilled talent easily move to other jobs in the US, mobility is more limited in Germany. In terms of federal science and technology policy, programs are dispersed across many agencies in the US. In Germany, the Federal Ministry of Education and Research (Bundesministerium für Bildung und Forschung), better known as the $\mathrm{BMBF}$, has a broad portfolio that includes most federal R\&D activities and programs to promote commercialization. The Federal Ministry of Economics and Technology, known by its German acronym BMWi, also has a range of technology and innovation programs. The "innovation rhetoric" differs in Germany and the United States, too, Mr. Beyer said. In the US, it is generally believed that government should play a limited role in industry and commerce. In Germany, "it is quite common to refer to government as a problem solver," Mr. Beyer said. Dr. Jäkel of BMWi pointed out that the German government has no qualms about providing "cradle to grave" financial assistance for R\&D and commercialization efforts by small- and medium-sized enterprises in the case of "market failure" by private lenders. The government has the right to intervene. The German system also distributes its R\&D investments very differently than the United States. While the US innovation system seeks breakthroughs in a broad spectrum of sciences and technologies, most German Research programs in Germany have tended to be dispersed across the country, making it difficult to develop regional innovation clusters that commercialize new technologies. Several public private initiatives have sought to form regional innovation clusters in emerging industries. The Fraunhofer institutes are leading a government effort to help consolidate research activities into 16 innovation clusters. An emerging bioenergy cluster based in North Rhine-Westphalia district, for example, has 17 regional partners from industry and academia. Other innovation clusters 
that the Fraunhofer institutes are helping to organize include one in optical technologies based in Jena, electronics for sustainable energy based in Nuremberg, turbine production technologies based in Aachen, and digital production based in Stuttgart. The BMBF also has a program to support regional innovation clusters. In 2007, the ministry launched the Top Cluster competition in which industrial strategic partnerships around Germany vied for $€ 200$ million in BMBF funds. The first five winners were an aviation cluster forming in the Hamburg region, Solar Valley in Mitteldeutschland (Middle Germany), energy-efficiency innovations in Saxony, and electronics and cell- and molecular-based medicine in the Rhine-Neckar metropolitan region. Innovation Alliances: New forms of German publicprivate partnerships are being encouraged to advance new technologies. One initiative is called "innovation alliances." Under the program, corporations must decide at the board level to co-invest with government. The German government is investing $€ 500$ million and private industry $€ 2.6$ billion in nine such alliances. Government funds are typically leveraged five-fold through private investment. An initiative for a cluster in molecular imaging for medical engineering, for example, includes Bayer Schering Pharma, Goehringer Ingelheim Pharma, and Siemens.

Despite its population of just 5.4 million, Finland has emerged as a global leader in innovation, consistently ranking the near top of the World Economic Forum's annual Global Competitiveness Index. Finland ranked No. 3 in innovation and No. 4 in overall competitiveness in the World Economic Forum Global Competitiveness Index for 2011-12. Finland has been acted as Europe's most innovative business environment. This has enabled the nation to restructure an economy that depended on pulp and paper for two-thirds of its exports in the 1960s to one dominated by electronics, most notably telecommunications equipment. Finland's economy also has grown faster than the OECD average both before and after the 2008 recession. Much of the credit goes to far-sighted government technology policies initiated in the 1980s that focus both on scientific research and on disseminating new technologies to industry. As a result, a close "Triple Helix" relationship has developed among Finnish universities, private industry, and government funding agencies. In 1981, R\&D accounted for around 1.2 percent of Finland's GDP. R\&D intensity increased significantly in the mid-1990s and by 2009 had risen to 4 percent of GDP, one of the highest levels in the world, before falling slightly to 3.9 
percent in 2010. Private companies accounted for 70 percent of Finnish R\&D spending in 2009, or $€ 4.85$ billion. Between 1992 and 2008, Finland's annual exports of high-tech products leapt more than five-fold, to $€ 11.4$ billion. But high-technology exports fell sharply in 2009 and 2010 as electronics and telecommunications products fell dramatically, primarily mobile phone sales. In addition to electronics and telecom equipment, Finland achieved dramatic export growth in energy technologies and chemicals. Finland's innovation system is guided by the Science and Technology Council, which issues broad technology investment recommendations every three years that other ministries and agencies use as guidelines for setting funding priorities. The council is chaired by Finland's prime minister and includes five cabinet ministers and representatives from industry, unions, and academia. There is a high degree of coordination between the Academy of Finland, which funds basic research, and Tekes, a Ministry of Trade and Industry agency that funds applied-research collaborations between the public and private sectors.

Japan has taken a number of actions since the mid-90s to improve its innovation system, many of them inspired by the United States. Japan has strengthened protection of intellectual property, overhauled science and technology policy institutions enacted its own version of the Bayh-Dole Act to make it easier for universities and research laboratories to commercialize technology, and bolstered industry and academic science partnerships. Japan also undertook a number of initiatives to increase entrepreneurialism, including a small-business loan program similar to America's Small Business Innovation Research program. To spur corporate $\mathrm{R} \& \mathrm{D}$ spending, Japan grants generous tax credits. Largely as a result, Japanese spending on research and development surged from 2.77 percent of GDP in 1994 to 3.8 percent in 2008 before declining slightly to 3.62 percent in 2009. Japanese companies account for three quarters of that spending, the highest ratio among OECD nations. Driving this change was the realization that innovation would be central to restoring growth to the Japan's stagnating economy in the wake of the financial crash of 1990. Even though Japanese R\&D investment and output of patents remained quite strong on world standards throughout the 1990s, Japanese companies stumbled as they tried to make the transition from products derived from well-developed technologies to the creation of more fundamental breakthroughs. Japan's competitiveness in industries such as 
semiconductors and consumer electronics waned with the rise of new rivals in South Korea and Taiwan. Japan had largely missed out on the U.S.-led booms in biotechnology and software. Japan's commercial scene, dominated by large conglomerates, was not producing many dynamic startups. The rapid pace of change ushered in by the information technology revolution and globalization did not play to the strengths of Japan's large industrial conglomerates. Japan's policy shift began in earnest with passage of the Basic Law on Science and Technology in 1995. Under that plan, the government spent $¥ 17$ trillion (\$206 billion in current US dollars) from 1996 through 2000 on science and technology programs. During the subsequent five-year basic plans, another $¥ 49$ trillion were invested. These funding increases helped Japanese universities and national laboratories upgrade laboratories that had become outdated. Japan also strengthened national coordination of its innovation strategy. The Council for Science and Technology Policy, established in 2001, became part of the Prime Minister's Cabinet. The council drafts comprehensive science and technology policies to respond to national and social needs, advises on how to allocate resources, and evaluates major projects. Funding focused on life sciences, nanotechnologies and new materials, information and communication, and environmental technologies. The government did not, however, assume greater central control over research. To the contrary, in 2004 it gave national universities and research institutes more autonomy to allocate resources, collaborate with industry, and set their own research priorities by separating them from the civil-service system. These institutions were transformed into non-profit corporations. Because they account for the bulk of scientific and technological research, the independence given universities and national labs is expected to allow resources to be used more flexibly and efficiently. In another crucial institutional reform, government agencies have begun to allocate much greater shares of R\&D funds on the basis of peer-reviewed competition. The greater focus on innovation has led to dramatic increases in scientific research in strategic areas. In 1992, the government set a goal of tripling investment in life sciences over the next decade. By 2001, the number of biotech companies had risen from a few dozen to 250; the goal was to have 1,000 biotech companies by 2010 . In nanotech, Japan was spending almost as much on research as the United States $-\$ 940$ million - as of 2004. Fuel cells, an important technology not only for portable electronic devices but 
also for future electrified vehicles, also received heavy emphasis. Robotics is another top Japanese research priority. The government is especially interested in developing technologies used in core components that can be applied across the industry, such as power sources, control systems, mechanics, software, and structures. Two of Japan's biggest investments in science were the $\$ 1$ billion Spring-8, one of the world's largest synchrotron radiation facilities, and the Earth Simulator, a $\$ 450$ million scientific computer billed as the worlds fastest when it opened in 2003. Japan also has resuscitated $R \& D$ consortia, a key element of industrial policy until the 1980s. The government cut funds for consortia in areas like semiconductors following trade friction with the US, but began to renew such programs after Sematech started to benefit US producers and Japanese chipmakers' fortunes decline. Stronger protection of intellectual property rights has improved Japan's innovation system since the early 1990s. Initially, the Japanese government responded to pressure from the US to strengthen enforcement of violations. The World Trade Organization's Trade-Related Aspects of Intellectual Property Rights (TRIPs) agreement in 1995 also had a major impact. The government enacted a series of other reforms since then, including the Basic Law on Intellectual Property in 2003 and establishment of the Intellectual Property High Court in 2005, which is modeled after the US Court of Appeals of the Federal Circuit. Criminal sanctions have been raised, and the scope of invention that is patentable has been greatly broadened ${ }^{24}$.

The dual faces of its economy define India's great innovation challenges. On the one hand, India is a global leader in information technology and business-process outsourcing services, which account for nearly $\$ 60$ billion in annual exports and employ more than 2.5 million $^{25}$. For the Indian government, however, the most urgent priorities in science and technology policy have been basic economic development. Although India's economic growth rate has accelerated sharply since 2003, the benefits of India's dynamic technology sectors have been slow to make a difference in the lives of hundreds of millions of people living in poverty. India is not just focused on improving its capacity to create new products,

\footnotetext{
${ }^{24}$ Wessner Charles W. Rising to the Challenge: U.S. Innovation Policy for Global Economy Committee on Comparative National Innovation Policies: Best Practice for the 21st Century. Board on Science, Technology, and Economic Policy, Policy and Global Affairs / Charles W. Wessner, Wolff, Editor. National Academy of Sciences, 1212.

${ }^{25}$ NASSCOM, “Indian IT-BPO Industry,” 2011. URL: http://www.nasscom.in/indian-itbpo-industry
} 
therefore. The Indian Government also now is paying more attention to what it calls "inclusive innovation", which is defined as "using innovation as a tool to eliminate disparity and meet the needs of the many" 26 . India suffers from inefficiency in transforming its S\&T investments into scientific knowledge (publications) as well as into commercially relevant knowledge (patents). ${ }^{27}$. To satisfy the demands of both industry and society, India must dramatically improve its national innovation system. India has enormous potential. It has an immense and growing pool of young Englishspeaking technology talent, a much younger population than China's, and a large Diaspora of overseas Indian technology entrepreneurs and researchers who are rebuilding ties in their homeland. India's economy is projected to grow by more than 7 percent a year for decades. India also has a highly innovative private sector and a number of elite higher-education institutes. India is an important high-tech $R \& D$ base for multinationals. Government controls around 70 percent of national $R \& D$ spending, and the biggest recipients have been areas relating to national security, such as atomic energy, aerospace, and ocean exploration. Venture capital is scarce. The talent pool is constrained by the facts that only around 12 percent of college-age Indians are enrolled in higher education, and only 16 percent of Indian manufacturers offer worker training, compared to 42 percent in South Korea and 92 percent in China. India produces only 6.000 Ph.D. a year in science and 1.000 - in engineering. There is little collaboration between India's 400 national laboratories and 400 national R\&D institutes and private companies. 70 percent of technologies developed by government-funded laboratories remain on the shelf and promote technology transfer and the commercialization of public R\&D. India's 358 universities and famed Indian Institutes of Technology, meanwhile, traditionally have played little role in commercializing technology. India also has several large initiatives to boost its global standing in strategic science and technologies areas. The government has more than tripled the budget for the Council of Scientific and Industrial Research, which oversees India's national laboratories, in recent years. It also has announced plans to establish 50 centers of excellence in science and technology over six years. Centers will include biotechnology, bio-informatics, nanomaterials, and high performance computing, and engineering and industrial

\footnotetext{
${ }^{26}$ National Innovation Council, Towards a More Inclusive and Innovative India, September 2010. URL: http://www.innovationcouncil.gov.in/downloads/NInC_english.pdf

${ }^{27}$ National Academy of Sciences, S\&T Strategies of Six Countries, op. cit., p. 43.
} 
design. They will offer doctorate programs and be based at existing institutions. India has big ambitions in nanotechnology. Under the 10 billion rupee ( $\$ 220$ million) National Science and Technology Nano Mission, created in 2006, three new R\&D institutes are being created. Some 50 to 60 science and technology institutes also are to be involved in building nanotech clusters across the country. The some $300 \mathrm{R} \& \mathrm{D}$ centers operated by multinationals in India are another powerful force connecting India to global innovation flows. In most emerging markets, multinationals set up research and product-development operations mainly to serve the needs of the local market. In India, however, foreign companies have tended to hire top engineering and design talent to help develop products sold around the world. According to one survey, the biggest reason multinationals invest in China is to access new consumer markets and to tap low-cost labor. In India, foreign companies cited new outsourcing opportunities and access to highly skilled labor as the biggest reason they invest there. India has become a closer partner with the United States in recent years. A 2005 bilateral agreement called for greater cooperation in civilian uses of nuclear, space, and dual-use technology. The two nations also concluded a 10-year framework agreement for defense. The US and India established a new joint science and technology endowment fund to facilitate research collaborations for industrial applications. A \$100 million U.S.-India Knowledge Initiative focuses on raising agricultural productivity and increasing agroindustrial business. The US and India also have launched a bilateral dialogue seeking cooperation in oil, gas, nuclear, cleancoal, and renewable energy sources and began discussing cooperation in civilian use of space.

Taiwan's rise from poverty in the 1950s to one of the world's premier high-tech powers has made it a role model of how to use science and technology policy for rapid economic development. Since the 1970s, the government has executed a systematic strategy to absorb advanced technologies from the West and Japan, develop globally competitive products and manufacturing processes, and then transfer the know-how to private companies to create world-class industries. These efforts quickly transformed Taiwan's economy. In 1981, food and textile industries accounted for 40 percent of Taiwan's manufacturing sector, with electronics accounting for less than 15 percent. By 2004, electronics was 35 percent of the island's manufacturing economy, with food and textiles 
accounting for less than 10 percent. Meanwhile, per-capita income in Taiwan rose from less than $\$ 500$ in the early 1950 s to $\$ 18,558$ in 2010 . Taiwan's standings in the areas of technology, advanced manufacturing, and knowledge-based industries have risen just as dramatically. Taiwan is the world's leading producer of mask ROMs and optical discs and the world's largest integrated circuit foundry producer and largest packager of integrated circuits. Taiwan is the second-largest producer of large high definition LCD panels, IC design services and crystalline silicon solar cells. Taiwanese industry is making impressive progress in next-generation industries such as solid-state lighting, thin-film electronics, photovoltaic cells, and biomedical devices using nano-scale materials. The portion of GDP devoted to research and development has risen more than fivefold since the late 1980s, and reached 2.9 percent of GDP in 2009. Taiwanese companies, once low spenders on $\mathrm{R} \& \mathrm{D}$, contributed more than 69.7 percent of total spending on research in Taiwan. The Island is beginning to excel in innovation as well. Taiwan is among the world leaders in US utility and design patents. Indeed, Taiwan generates more patents per 1 million citizens than any other region or nation. Taiwan also has been winning international innovation awards. National research institutes had three winning entries in R\&D Magazine's 2010 R\&D top 100 Awards, for example. One was for FlexUPD, billed as the first technology to enable the commercialization of paper-thin, low-cost, flexible flat-display panels for electronic products. Taiwan also won awards for a display technology that allows both 2D and 3D information to be viewed simultaneously with the naked eye and for the first non-toxic, fire-resistant composite technology. What's more, Taiwan's science and technology investments have enabled the economy to meet one of its most crucial strategic challenges: remaining a globally relevant sector in the wake of a rising China. Its giant neighbor has lower costs, vastly more engineers and scientists, and aggressive policies targeting all of the same industries as Taiwan. Despite a massive shift of factory work to the mainland, the value of Taiwanese exports continues to rise. Taiwan had record exports in 2010 of $\$ 275$ billion, with 42 percent going to China, up from 24 percent in 2000. Taiwan is reaping the benefits of heavy investments in education and decades of comprehensive science and technology policies aimed at building globally competitive industries. The island of 23 million also has expertly leveraged its strategic geographic 
location off the coast of China. Estimates of Taiwanese investment in mainland China, including those made through third parties range from $\$ 150$ billion to $\$ 300$ billion. Taiwanese companies control and manage much of the electronics export sector. Taiwan has positioned itself as a global engineering and innovation hub bridging East and West.

The express purpose of Taiwanese government science and technology policies has always been to establish and sustain domestic industries. The island started in electronics manufacturing with duty-free export zones in the 1960s, when Taiwanese wages were extremely low. In the 1970s, it began investing heavily in industrial technology institutes to stimulate more sophisticated indigenous industries. Ninety-two percent of R\&D was devoted to manufacturing as of 2006, compared to 65 percent in the United States and 83 percent in South Korea. Of that, 69 percent was devoted to high-tech manufacturing. The key elements of the Taiwan method have been to carefully identify industries where the island can make its mark, rather than attempt to invent new technologies from $\operatorname{scratch}^{28}$. Taiwan's strategy has been to focus on technologies that multinationals already possess and that Taiwanese companies want to apply. Then the government develops the necessary skills base, builds or upgrades common laboratory facilities, and systematically acquires the needed technologies through a combination of licensing, in-house $R \& D$, and partnerships with foreign companies and universities. The backbone of Taiwan's strategy has been its industrial research institutes. ITRI is by far the biggest. Established in 1973, ITRI has grown to a network of 13 research centers that focus on information and communications, advanced manufacturing, biomedical, nanotechnology and new materials, and energy and environmental technologies. More than 60 percent of ITRI's 6,000 employees hold master's or doctorate degrees. ITRI consults with more than 30,000 domestic companies each year. It has helped create 165 start-ups and spinoffs, and generated more than 10,000 patents. More than 20,000 ITRI alumni work in Taiwan's private sector, around 5,000 of them holding senior executive positions Hsinchu Science Park. International collaboration is likely to become a more important aspect of Taiwanese innovation strategy. ITRI already has extensive overseas ties. In addition to the relationship with the Media Lab, ITRI works with MIT's

\footnotetext{
${ }^{28}$ Innovation Policies for the 21st Century: Report of a Symposium, Charles W. Wessner, editor, Washington, DC: The National Academies Press, 2007.
} 
artificial intelligence lab. ITRI has joint research programs with the University of California at Berkeley in nanotechnology and clean energy, five labs at Carnegie Mellon University, and a strong relationship with Stanford Research Institute. Among its many other collaborations are projects with Japan's RIKEN, the University of Tokyo, the Netherlands' Organization for Applied Scientific Research, Russia's Ioffe PhysicalTechnical Institute, and Australia's Commonwealth Scientific and Industrial Research Organization. ITRI's long list of multinational partners includes Corning, Broadcom, Sun Microsystems, Hewlett Packard, Bayer, BASF, ARM, GSK, and Nokia.

Science and technology policy has been central to Singapore's emergence as one of the world's wealthiest nations. Since separating from Malaysia in 1965, per-capita income has soared from a mere \$512 to $\$ 42,653$ in 2009. Like Taiwan, Singapore's takeoff was fueled first by labor-intensive manufacturing in the 1960s. Singapore then thrived as an Asian hub for trade, services, manufacturing, and corporate product development. Now the island of 5.1 million aspires to become one of the world's premier innovation zones for 21 st century knowledge industries. As the government's science and technology plan for 2006-2010 stated that the crucial success factor for Singapore will be its ability to become an international talent node-nurturing its own talent as well as drawing creative and talented people from all corners of the world to live and work in Singapore. Singapore is making impressive progress. The nation's heavy investments in higher education and $R \& D$ infrastructure and ability to execute visionary and comprehensive innovation policies has enabled the country to reinvent itself as a magnet for multinational research labs and top-notch international talent in fields such as genomics, infectious diseases, advanced materials, and information technology. R\&D manpower more than doubled between 1998 and 2009 to 41,388, research organizations increased from 604 to 854 , and total R\&D spending more than doubled to US $\$ 6.04$ billion, despite contracting by 15 percent from 2008 levels because of a sharp decline in private sector $R \& D$ as a result of the global recession. Singapore ranks No. 2 worldwide in global competitiveness. Singapore's innovation system is built upon a strong foundation in education. The share of university graduates in the population leapt from 4.5 percent in 1990 to 23 percent in 2010, and the portion of the resident workers with degrees jumped from 14.6 percent to 
27.8 percent between 1999 and June 2010. More than 153,000 students were studying at the nation's universities and polytechnics as of 2009. Singapore grade-schoolers perennially rank at or near the top in math and science scores. The government's strong commitment to science and technology encourages students to pursue those fields, and the highly skilled workforce in turn enables Singapore to frequently transform itself, explained Yena Lim of the Singapore Agency for Science, Technology, and Research. In terms of international patents, start-ups, and the dynamism of domestic companies, Singapore is still far from an innovation powerhouse. The government has charted an ambitious agency to push its innovation system to a higher level. The Agency for Science, Technology, and Research (A*STAR) leads many of the programs aimed at making Singapore a global R\&D base. A*STAR spearheads efforts to develop clusters in high value-added manufacturing, such as microelectronics, new materials, chemicals, and information and communications equipment, and the rapidly growing biomedical sector. The agency also manages Singapore's ambitious new multibillion-dollar science parks, Biopolis and Fusionopolis, which combine a high concentration of public and corporate research organizations in a contemporary urban setting. A*STAR also leads Singapore's aggressive efforts to recruit top international scientists and to develop homegrown talent. Its policy is described as "pro-foreign and pro-local".

South Korea has grown tremendously over the last 30 years by following a strategic approach to science, technology, and innovation to create world-class companies. In technology innovation, South Korea's success in leapfrogging technology generations has been underscored by a pragmatic strategy of starting at the low end of the market in new product segments and continuously improving their product sophistication, using economies of scale to secure a competitive market share.

South Korea's industry and economy is dominated by business conglomerates called chaebol (Samsung, Hyundai, Pohang Iron and Steel Company, and LG electronics). These companies have moved from safe technology investments and incremental innovation toward cutting-edge science-based innovation by adopting Western business practices; as the country has developed, South Korea's historical focus on manufacturing has shifted to services and investing in research and development (R\&D) at the forefront of technology. In a Booz \& Company ranking (The 2012 
Global Innovation 1000: Key Findings), Samsung is ranked fourth among the world's most innovative companies, behind Apple, Google, and 3M. In a different ranking of innovative companies ("The Most Innovative Companies 2012: The State of the Art in Leading Industries"), Hyundai gained the top spot among the automotive companies moving up 12 rankings in the past 2 years to surpass Toyota. The South Korean private sector's strengths provide opportunities for the country to continue on its innovation trajectory. But South Korean business practices face challenges as well. While the chaebol culture is a source of South Korea's success, it is not a transparent culture, and many of its business practices are considered corrupt. The growth of the chaebol has come at the expense of small and medium sized companies, as they attract the top talent in the country, creating a dichotomous economy. The presence of the chaebol also creates obstacles for entrepreneurs and has depressed the prospects of a venture-backed, start-up culture. South Korean social issues also pose threats to continued success.

This analysis of South Korea's innovation system shows that:

1. Both governance and socio-economic factors play important roles in determining how well a country is able to use its endowments to create a strong national innovation system.

2. A high-quality of education, particularly in the STEM fields, is foundational for developing the human capital needed for an innovationdriven economy.

3. Consistent, long-term investments in research and development are instrumental in achieving a leadership position in technology-based fields. The South Korean government supports long-term research in the basic sciences and defense technologies while the private sector is the primary funder of applied research.

4. An underdeveloped and uncompetitive small and medium enterprise sector can reduce the capacity for innovation in the overall economy.

5. Finally, in today's globalized economy, countries and companies are increasingly looking outward to learn about other cultures and increase their ability to be responsive to their global customers in a competitive market $^{29}$.

\footnotetext{
${ }^{29}$ Gupta David W Nayanee. Innovation Policies of South Korea / Nayanee Gupta David W. Healey Aliza M. Stein Stephanie S. Shipp. Institute for defense analyses, 2013. IDA Document D-4984. 71 p.
} 
The South Korean government has developed a robust science and technology capacity following two parallel tracks: 1) creation of a state-led research and educational capacity; 2) corporate research and development efforts by the country's large conglomerates. The government's science and technology policy is implemented in the form of Science and Technology Basic Plans every 5 years. The most recent, the 577 Initiative focuses on sector-specific strategies, including automobiles, shipbuilding, semiconductors, steel, machinery, textiles, and materials. South Korea is also developing in the three broad areas of green technologies, value-added services, and technology convergence, such as the convergence of telecommunications and network technologies into a single system or device.

South Korea has focused historically on manufacturing but has shifted the focus to services and creation of a knowledge economy as the nation has developed. To achieve the goal of increasing $R \& D$ investments as a share of gross domestic product (GDP), the government launched a variety of financial incentives to encourage private investment in $R \& D$, notably by encouraging private financial institutions to turn their collateral-based loans into technological value-based loans. The government also spends extensively on infrastructure. Korea is ranked thirteenth in the world in infrastructure, and leads in broadband penetration. The government's investments have been largely effective in spurring S\&T-based innovation and progress. South Korean companies have achieved high levels of global competitiveness in leading edge technologies, ranking second globally (behind the United States) in innovation in 2013. Over the past two decades, South Korea has transformed itself into a leading innovator by adopting Western business practices and making aggressive R\&D investments while capitalizing on the strengths of a consolidated manufacturing supply 5 chains. Today, innovation in the South Korean economy is primarily driven by the private sector, which is dominated by chaebol, such as Samsung, Hyundai, Pohang Iron and Steel Company (POSCO), and LG electronics. These firms typically span a broad spectrum of related and unrelated businesses and control about $70 \%$ of South Korea's total spending on R\&D (with government contributing about $25 \%$ ). For example, Samsung is diversified across the food, infrastructure, shipbuilding, life insurance, surveillance, recreation, advertising, and financial industries, among others, leading many to refer to South Korea as the "Republic of Samsung" South Korean companies have moved from 
safe technology investments and incremental innovation toward cuttingedge science-based innovation. Capitalizing on future possibilities in science and technology requires disruption and risk taking. Koreans prize efficiency; their desire for success leads them to be highly strategic in their approach. They emphasize planning for R\&D in government and industry and using metrics to track success. The government's long-term (technology agnostic) investments in basic science R\&D, raised standards for universities, and emphasis on global collaborations will secure Korea's evolution of a knowledge-based economy, but only if paired with an increasing tolerance for risk taking.

South Korea's economic success followed aggressive industrial development on the part of the government and the pursuit of an exportdriven economy. Additionally, the government nurtured close ties with the large, family-owned industrial conglomerates known as chaebol that have dominated the Korean economy for decades. During this crucial developmental time, the Korean industry had import and FDI restrictions, direct credit, and tax relief, which allowed it to develop in a protected economic environment and become internationally competitive. The government, in turn, wielded influence through industrial policy, choosing and nurturing strategic industry sectors like shipping, refining, and semiconductors. Exports from the huge multinational chaebol continue to drive the Korean economy, and their competitiveness drives innovation. The four largest chaebol: Samsung, Hyundai, LG, and SK2 are strong in a wide range of activities from automobiles to shipping to banking to tourism to consumer electronics. Continued government assistance and economies of scale allow the chaebol to be extremely competitive. South Korea is currently the largest shipbuilder in the world, with close to $50 \%$ of the world market; the largest electronics company (Samsung) ${ }^{30}$; and the eighth largest auto maker (Hyundai). The southeastern industrial district of Ulsan alone contains the largest automobile factory, the largest shipyard, and the third largest oil refinery in the world. South Korea is also a major player in the manufacture of liquid crystal displays (LCDs), which now account for $5 \%$ of exports.

The S\&T policy governance structure in South Korea in many ways resembles that of the United States. The two main advisory and

\footnotetext{
${ }^{30}$ Bishop W. The Elements of Leadership in a Global Environment. URL: https://onlinelibrary.wiley.com/ doi/abs/10.1002/joe.21505
} 
coordination bodies serving the executive branch are the South Korean National Science and Technology Council (NSTC) and the Presidential Advisory Council on Science \& Technology (PACST). The two ministries most responsible for setting innovation policy in South Korea are the Ministry of Education, Science, and Technology (MEST) and the Ministry of Knowledge Economy (MKE). MEST is the most influential, as it is primarily responsible for formulating policies for S\&T development and $\mathrm{R} \& \mathrm{D}$ investment and supporting the nation's universities and research institutes (both government and private). MKE, on the other hand, works primarily with industry. Technology selection considers a large number of factors, including US S\&T policy. The National Science and Technology Commission's technology planning and investment is a consensus-based adaptation of US and European Union science, technology, and innovation plans. The programmatic technology selection is based on input from evaluation studies. This approach has been criticized for putting excessive pressure on researchers, incentivizing short-term research, and therefore dampening creativity in scientific research ${ }^{31}$. At the operational level, the MKE and MEST have the power to allocate about 30\% of the R\&D budget. The MKE's science, technology, and innovation policy is implemented in the form of Science and Technology Basic Plans every 5 years. Since the implementation of the first of four S\&T Basic Plans in the late 1990s, the government has emphasized investment in $R \& D$, highlighting the role of researchers in the economy and strengthening innovation policy.

Over the past two decades, Korea has systematically built up a globalsavvy brain trust by strategic external sourcing and assimilation of knowledge at the university and workforce education levels. This statepromoted endeavor, reinforced by its education focused culture, gives Korea an advantage over Japan. In the past decade, leading Korean firms such as Samsung and Hyundai have been incorporating western business practices into their "Japanese system", disrupting the traditional organizational structure by bringing in outsiders into an insular culture and sending company executives overseas to get first-hand experience of foreign markets, resulting in knowledge sourcing on a global 26 scale. This has allowed them to succeed in understanding the customer in

\footnotetext{
${ }^{31}$ Mahlich Jorg. Korean Science and Technology in an International Perspective / Mahlich Jorg, Pascha Werner. Physica-Verlag Heidelberg, 2012. 288 p.
} 
emerging markets, while also improving their marketing and design competencies to gain recognition in established markets. In addition, there are several Korean organizations such as the Korea-US Science Cooperation Center (KUSCO), a non-profit that sponsors about 140 students yearly for 18-month internships at US companies. These internships immerse students in business, accounting, marketing, and public relations functions. The number of Korean students going overseas for university education has steadily increased over the past two decades, increasing $32 \%$ between 2006 and 2011 and is the highest with 19.99 per 10,000 people, followed by Japan (4.92), China (3.07), and India (1.19) (APEC 2008). The United States is the top destination for students, followed by China and Japan. While STEM fields account for $25 \%$ of enrollment, business management and social studies degrees (areas where Korean universities are particularly weak) attract more than $40 \%$ of Korean foreign students (Institute of International Education (IIE) 2012). Private R\&D Investment Business innovation in South Korea has been accelerated by substantial R\&D investments by South Korean industry over the past decade. Samsung's R\&D investment has doubled over the past 3 years from $\$ 6$ billion in 2009 to $\$ 12$ billion in 2012 (with an additional $\$ 30$ billion in facilities and capital investments), going mainly to research in memory chips, LED displays, and systems-on-chip, a next generation semiconductor technology. As a comparison, leading competitors Intel Corp spent $\$ 11$ billion in 2012, and Taiwan Semiconductor Manufacturing Corporation (TSMC) spent \$9 billion in 2013 (Gupta, Kim, and Levine 2013). Hyundai Motor spent \$12 billion on R\&D and facilities in 2012 (compared with Toyota which spent $\$ 9.9$ billion in 2011). Of the $\$ 12$ billion, $\$ 4.4$ billion was allocated to fuel efficient cars (Beene 2012). Patenting activity in top Korean companies has risen to fourth place behind the United States, China, and Japan. Korea follows the United States in nanotechnology patents (Shapira and Wang 2010). More significant than the increase in number of patents is the trend in types of patents. While patents were predominantly process and product patents 10 years ago, with the chaebol increasing their investments in fundamental research, the number of patents related to platform technologies is slowly increasing, an indicator of growing expertise at the forefront of new technology paradigms. For example, Samsung, a leading competitor in the smartphone industry, is also gaining ground in the battle on patenting 
technological platforms (such as $4 \mathrm{G}$ ) on which future telecommunications services will be delivered.

South Korea's chosen route to industrial catch-up has its drawbacks. The legacy of siphoning off capital, top talent, and other resources toward developing South Korea's industrial chaebol has come at the cost of a widening gap between big and small firms, and between manufacturing and services. It has created a sharp dichotomy in the industry, a world with "a few big fish and lots of minnows". Outside the chaebol, much of Korean industry is imitative and faces low profit margins and competition from China and other foreign competitors. SMEs, which supply parts and components to the chaebol are disenfranchised compared to their counterparts in Japan and Taiwan (which operate in a similar structure) in that they are locked into fairly closed production networks with very limited decision-making power, which has denied them learning opportunities with diverse firms, both foreign and domestic, to improve internal competitiveness. Recently, the government has been pushing for financial incentives and technology commercialization opportunities for small and medium-sized firms (although the human capital equation is difficult to address, as employment by chaebol is far more socially prestigious), and their effectiveness remains to be seen. South Korea's service sector is the second smallest in the OECD area, accounting for almost 58\% of its GDP (OECD 2012). Only 4 of its 30 largest enterprises are in services; small and medium-sized companies dominate the service sector, accounting for about $80 \%$ of output and $90 \%$ of employment. Productivity in services is $53 \%$ of the productivity level of the manufacturing sector, much below the OECD average of 87\%; this mirrors the ratio of wages between the two sectors.

The Chinese government set out its research policy requirements in plans such as the National Medium- and Long-Term Program for Science and Technology Development (2006-2020) and the 12th Five-Year Plan (2011-2015). These include the objective of increasing research and development $(R \& D)$ expenditure to a minimum of 2.5 percent of GDP per year in the period up to 2020 . By that same deadline, only 30 percent of the technology needed is to be imported from abroad and Chinese scientists should rank among the world's Top 5 when it comes to patents and citations. 
With this "innovation initiative", China wants to establish itself as a location for the development and production of high-technology products. The aim is to overcome the technology gap and become a technology leader. The associated set of measures reflects the government's determination to transform China into an innovation-focused nation by 2020 - one that exports cutting-edge technologies and successfully competes with the world's leading industrialized nations. Concrete measures include significantly increased investment in science and technology (S\&T), tax incentives, financial assistance in government procurement, protection of intellectual property rights (IPR) and the promotion of young scientists. China wants to develop an economy which combines the service industry with a modern manufacturing industry. Renewable energies, materials, environmental protection, biopharmaceuticals, telecommunications and internet applications are all deemed strategically important industries.

Investment in higher education has risen steadily in China in recent years as well. Public expenditure on higher education almost quadrupled in the period 2006 to 2012. To ensure that China's higher education institutions join the world's elite, various funding quantitatively speaking, China is already one of the strongest research countries in the world. In the past fifteen years, it has increased its $R \& D$ expenditure as a share of GDP from 0.9 percent (2000) to 1.32 percent (2005) and then to 2.08 percent (2013). In 2015, R\&D expenditure is expected to amount to 2.2 percent of GDP. The 2.5 percent goal for 2020 appears to be reachable. Since 2001, R\&D expenditure has risen by just under 17 percent per year, in absolute terms.

China could soon overtake the US as number one. In 2013, China spent some $\$ 336.5$ billion (approximately EUR 253 billion) on R\&D (this compares with $\$ 457$ billion/EUR 344 billion in the U.S., and $\$ 101$ billion/ EUR 76 billion in Germany).

Another impressive example of the rapid development of China's R\&D sector is the number of its patent applications. Since the country's first patent law entered into force in 1985, the number of patent applications initially rose slowly, but by the end of the 1990s, it was growing dramatically. In 2014, some 928.000 patents were applied for in China (of which 127.000 were from abroad). Approximately one in four of these were approved. Of the approved patents, one in three came from outside China (70.548 out of 233.228). As regards the number of patent 
applications submitted under the Patent Cooperation Treaty, China overtook Germany in 2011 and ranked third behind the US and Japan in were introduced to give selected institutions the financial assistance they need to become top-class research establishments.

China's political system is controlled centrally from Beijing and, despite earlier decentralization measures, tends to take a more top-down approach. Nonetheless, provincial governments and other stakeholders (such as local and regional science and technology commissions) are playing an increasingly important role in China's innovation landscape. Since the 11th Five-Year Plan (2006-2010) was implemented, the plans have been less in the nature of "instructions" from central government and take more of a macromanagement approach. This gives the provincial governments enough autonomy to define their own research policy focus areas while adhering to the strategic requirements and to decide independently on how to spend the available budget. In many instances, the regional and local stakeholders are more flexible and thus faster in their decision-making than institutions operating at central level. Under the $11^{\text {th }}$ Five Year Plan, the city of Beijing for instance spent a total of RMB 75.8 billion (about EUR 9.1 billion) on some 1,200 projects. To secure a better position in countrywide competition, regional and local stakeholders expend great effort in establishing international contacts, in some cases financing a significant portion of the costs of cooperation projects conducted with foreign partners and offering incentives for foreign research centers to set up premises in the respective regions, 2014 with 25.539 patents. It must, however, be noted that the growing number of patent applications is by no means an indication of their quality and innovative content. This is partly due to distorted state incentive systems (with a focus on incremental innovation and design adaptation for the Chinese market, applications for 'junk patents' and copyright and trademark patents rather than on invention patents). Despite the strong rise in the registration of domestic patents in recent years, China is spending almost twenty-four times more on the use of foreign IPR than it generates in revenue from Chinese IPR. The estimated expenditure incurred by German research, funding and intermediary institutions in their cooperation with China, has grown considerably in recent years. While spending in 2006 amounted to EUR 26.3 million, it had risen to EUR 40.7 million in 2010 and to EUR 46.5 million in 2014. 
These cooperation activities are largely defined by the respective roles and missions of the German research organizations within the research system, their respective internationalization strategies and their overarching goals and objectives. Depending on the reason for the cooperation, these can include not only the primary research goals, but other objectives such as strengthening Germany's image as a research location (by securing its international compatibility) and direct and indirect benefits to German industry.

The Max Planck Society (MPG) has collaborated with the CAS since 1974. Particularly noteworthy in this regard are the CAS-MPG Partner Institute for Computational Biology in Shanghai, the establishment of independent young researcher groups in China in line with the MPG model (12 groups since 1995) and the Max Planck partner groups (over 30 established since 1999) run by young Chinese scientists who prior to founding the groups had held a post-graduate position at a Max Planck institute for at least one year. The Helmholtz Association of German Research Centers (HGF) has had an office in Beijing for more than ten years. Apart from the cooperation activities of individual Helmholtz institutes, the Helmholtz-CAS Joint Research Groups should also be highlighted. More than a third of the almost 90 institutes belonging to the Leibniz Association have established relations with China; some institutes have maintained a local presence with their Chinese partners for many years. The Fraunhofer-Gesellschaft (FhG) has been represented in Beijing since as far back as 1999. This presence forms a bridge to Chinese partners such as the CAS and the Chinese Academy of Engineering. The FhG also cooperates with a large number of universities, including Tsinghua, Tongji and Shanghai Jiao Tong, and with institutes of the Beijing Academy of Science and Technology, the Shanghai Academy of Estimates based on figures provided by the MPG, the HGF, the FhG, the DFG, the AvH and the DAAD. In the case of the AvH and the DAAD, figures include funding managed on behalf of the BMBF under international programs involving cooperation with China.

Science and Technology, and the Shandong Academy of Sciences in 2007, the FhG and the CAS established jointly funded programs for Chinese postgraduate students. The aim of all FhG projects in China is to work with excellent research partners on topics which in the light of the country's dynamic economic growth and rapid urbanization require 
qualitative and quantitative technological solutions. Fields of interest include environmental technologies, infrastructure, transportation and energy-efficient buildings in megacities, and public health. The German National Academy of Sciences Leopoldina maintains contact with China in the form of mutual delegation visits and symposiums held with Chinese partners on varying topics in both Germany and China.

In Brazil, most public R\&D is not mission-oriented. For instance, only $30 \%$ of Brazil's R\&D resources are connected to institutions and ministries whose mission is to solve problems in the areas of health and agriculture. In the North American case, more than $90 \%$ of publicly funded R\&D is results oriented. Thus, the suggestion here is that we maintain the budget for S\&T currently overseen by the MCTI and MEC, but that we create conditions that enable sectoral ministries to foster R\&D programs that are directed towards solving Brazil's concrete problems. This would involve: Increasing the investments in R\&D in sectoral ministries, such as Health, Energy, Defense, Agriculture, etc., and using these investments to solve concrete problems, such as i) developing medication and vaccines for SUS, the Brazilian Unified Health Care System; ii) developing technologies to increase energy efficiency or reduce water consumption (so as to alleviate the water crisis); iii) developing new telemedicine technology systems in order to increase efficiency and reduce the costs of our health care system; and iv) developing depollution technologies. Training staff in sectoral ministries on how to contract and follow up this type of investment. Adding explicit and clear mechanisms allowing public sector agencies to contract R\&D. Article 20 of the Innovation Law already stipulates this possibility, but law needs to be improved in order to give more legal guarantees to public managers and establish new ways to contact the suppliers. Reinforcing policies are using government procurement power and applying demand-side innovation instruments in the innovation policy mix. The focus should extend beyond the procurement power. For instance INMETRO has a major potential to guide demand though industrial standards. According to several existing criteria, Brazil has one of the most closed economies in the world. In Brazil, the total trade flow represents just over $20 \%$ of the GDP and import tariffs (nominal or effective ones) are among the highest in the world. However, Brazil is not only a "closed" country in terms commerce. It is also a country that is closed to ideas. The number of Brazilian students and researchers living abroad is quite small, 
even though this number has risen, mainly among undergraduate students, as a result of the CsF Program. The number of foreign students, researchers and industrial technicians in Brazil is even smaller. This lack of openness has implications that affect the Brazilian economy's innovation capacity in at least two major ways. First, this lack of openness limits their capacity to follow changes on the world's technological frontier. The time it takes to incorporate state-of-the-art technology produced abroad is an obstacle to Brazil's capacity to generate relevant science and innovation when compared to international standards. Moreover, a dynamic innovation system is characterized by the constant flow of ideas and people. Due to this lack of openness, several data measures describing the world's flows of knowledge make it evident that Brazil is on the margins of these flows.

The second aspect of the Brazil's lack of openness has to do with competition. In a capitalist economy, the engine of innovation is the search for the extraordinary profit that can be derived from new ideas. In an economy in which the market is protected from competition, the incentives for innovation are not as great. Hence, it is important for the Brazilian economy to adopt some strategies, including the following: moving towards a greater openness in relation to the international market, in a gradual and transparent way, starting with segments in which the positive impacts resulting from this openness (gains in efficiency resulting from access to new technologies incorporated into some capital goods or reduction of the price of imported inputs) are greater; developing incentives and mechanisms that will attract foreign researchers to work at Brazilian universities, companies and research institutes; facilitating the granting of work visas to foreign professionals, with a greater focus on highly qualified workers; creating swift and low-cost mechanisms (reducing tariffs whenever necessary) for importing inputs, research equipment, and prototypes; Prioritizing programs to send Ph.D. students and post-doctoral researchers in fields of specific interest abroad; allowing public Brazilian universities to hire foreign professors; encouraging learning and use of English in society as a whole, and particularly in undergraduate courses.

\section{Recommended innovation strategy for Ukraine}

A complex and bureaucratic institutional environment discourages investment, especially investment in innovation. Estimates made by Ipea's 
team show that the impacts of an improvement in the World Bank's Doing Business publication on investments and productivity would be substantial. From the perspective of innovation, these difficulties manifest themselves in many areas, including the follow: i) the time required for a patent to be granted; ii) the time and requirements necessary for approval of research or new medications by the National Health Surveillance Agency (ANVISA); iii) the existing restrictions on opening and closing companies; iv) the regulation of investments made with venture capital funds; v) the difficulty associated with importing inputs and research equipment; vi) the operational difficulties involved in funding research institutions using public resources; vii) the difficult relationship between universities and companies; and viii) the time spent on due diligence. The difficulties pointed bellow and the level at which they affect the innovation system in Brazil are diverse and require systematization. Thus, a priori, some basic strategies are as follows:

1. Consolidating an agenda for improving Brazil's business environment and tracking progress in this area; identifying exactly which norms, regulations, and legislation could be modified in order to improve our institutional environment for innovation.

2. Reformulating and modernizing the Innovation Law. A new law was created in 2016, but its paralegal instruments must be straightforward and easy to execute. Additionally, the controlling agencies must be made aware of the legal possibilities.

3. Reviewing the legislation governing the opening and closing of companies in order to facilitate and expedite this process, and to encourage entrepreneurship.

4. Reducing the bureaucracy associated with $R \& D$, especially in the life sciences. In this sense, the Biodiversity Law was a step forward, but needs to be followed up and modernized frequently.

5. Streamlining the process by which researchers from public institutions can develop innovation projects and offer consultancies to companies.

6. Eliminating all public policy instruments that discourage innovation processes. An example is the basic production process associated with the Informatics Law, Lei de Informática, which establishes manufacturing norms in order for companies to have access to tax incentives. An innovation, by definition, will not be covered by the PPB. 
7. Jointly with control agencies, building a clear and consensual understanding with regard to the legal limits and possibilities of public managers when fostering innovation, in a way that encourages control and efficiency, but does not hinder our technological progress ${ }^{32}$.

Australia's experience will be useful for Ukrainian innovative strategy. There Innovation System actively discourages and disincentives true innovation. The vast majority of Commonwealth spend on (so-called) "innovation" is actually spent supporting invention and a relatively lesser portion supports true innovation. Invention is the realm of research and discovery, basic science and the development of new ideas and knowledge. Innovation on the other hand is the new and successful application of those ideas to address issues. The distinction between invention and innovation is important because the blurred lines in popular/vernacular usage create structural flaws in our innovation systems. Australia's academics are a significant intellectual resource. As a national priority needs active drive, facilitate or contribute to true innovation at all levels of society. Australia's innovation systems however, squander this resource. Through incentives policies we explicitly encourage and manage our academics to reprioritize commercialization of their work and to pursue instead a model governed almost exclusively by publication and citation. Australian industry has a very poor record of collaboration (with suppliers, customers and especially with academia) and, as a broad generalization, consequently fails to recognize, develop or implement many progressive innovations that could otherwise result. Significant and frequent changes to government-driven innovation support systems available to industry greatly complicate the landscape for companies, particularly SMEs, and make it hard for them to embrace that support. Widespread technology literacy greatly enhances efforts to encourage innovation. We don't have this literacy in Australia the issue arises in primary schools and is entrenched through the secondary system. Unfortunately schooling systems operate without a nationally coordinated strategy for the STEM subjects (science, technology, engineering and mathematics). A knock-on effect is a lack of school leavers emerging from that system with a passion for technology, which in turn for instance leaves Australia near the bottom of the OECD rankings for the number of engineers per head of population - a metric that correlates

\footnotetext{
${ }^{32}$ Negri Fernanda De Negri, Innovation policies in Brazil during the 2000s: the need for new paths / Fernanda De Negri, Andre Tortato Rauen. Institute for Applied Economic Research - ipea 2018. 60 p.
} 
strongly with economic growth. These issues are not unrelated. They are heavily interconnected and in many cases represent direct cause and effect. The measures to address these issues are equally interconnected.

Australians have a long a successful record of inventing. Despite significant ingenuity and capacity for innovation, we have by contrast a poor record of implementing and delivering sustained innovation. Historically there are many fine examples of excellent Australian innovations; however they stand alone as isolated examples. Typically national system and institutions strongly support and encourage invention, and they hope that innovations will magically arise from that. Sometimes they do. But they are yet to successfully systematize or institutionalize the transition from invention to innovation; rather they seem to rely on a presumed good fortune here in The Lucky Country to carry the day. Innovation is not invention, and it doesn't happen by accident. They are different. Basic research and ideas generation is invention. Australia has a good track record of invention - "we encourage it, we incentivize for it". By contrast, innovation is "ideas, successfully applied" - and this they need to get significantly better at. Unfortunately the terms are mixed in common usage with the distinction between them often lost. For instance whilst Australian public spending on "innovation" (a term as used by government departments, treasury, etc.) has averaged the best part of A $\$ 8-9 \mathrm{bn} /$ year over the last decade, at most a quarter of those funds (partitioned on a very generous basis) are spent supporting actual innovation. By contrast the bulk of Australia's public spending on (so called) "innovation" is actually spent on more basic research - on invention.

The typical/traditional model of intellectual property (IP) management at most Australian universities aims to derive significant revenue (well, as much as "possible") from patented IP. This is simply a direct outcome of today's university funding models that encourage/require universities to source as much additional revenue from anywhere to further the institution's core missions. There are two standard flaws in the normal approach: not uncommonly efforts to exploit that IP are pursued on terms that are unrealistic for companies (especially startups, but also for existing SME and large enterprises), and more often than not the IP is not successfully used by anyone. The perceived value of the IP being licensed is often overstated, and the need to generate a financial return is too highly prioritized by the university's technology transfer offices. When such IP is 
successfully licensed to some commercialization effort (either an existing company or a new startup), the arrangement between the university and the relevant academic(s) that were the source of the invention/IP are usually considered by the academics to be of poor net value in comparison with the time, difficulty and strain involved in negotiating the agreements. The opportunity cost for the academic is simply too high to divert them from pursuing academic research and generating research output (publications).

\section{CONCLUSIONS}

Even if an invention has been captured in a patent, then as per the details above, academics find there is often little incentive to seek to commercialize their inventions. If it happens, great (The Lucky Country at work again!), but if not there are more important things to pursue. From the perspective of local industry it is a commonly expressed sentiment that collaborating with academia is harder than it should be. As above - there are reasons that motivate that outcome. From a national perspective, we have a very small pool of local enterprises (far too few) that are willing to engage and collaborate with academia - by and large Australian companies simply do not collaborate with academia. By contrast we need a system that encourages that outcome. To build a vibrant innovation culture in Australia we need a much bigger pool of companies that will collaborate with academia. Today's academics can/should be incentivized to form new enterprises/start-ups for many reasons, including:

- to exploit and commercialize their own existing and future inventions, i.e., those ideas they have developed themselves;

- by encouraging academics to cross over into commercialization, create a new pool of $\mathrm{SME}(\mathrm{s})$ that can and are willing to engage in collaborative effort with academia (as initially they'll be "collaborating" with themselves);

- and most significantly, to expand the number of local enterprises with positive collaboration experiences that will share their stories and encourage in others (their peers) a willingness to engage in collaborative efforts with academia Today's academics can seed and encourage an expanded pool of willing and enthusiastic SMEs.

To kick-start a vibrant local innovation ecosystem the nation, with government leadership on this score need to boot-strap a new cohort of (young) companies that are enthusiastic about innovation and engaging 
with the intellectual power resources available. Success breeds success, and we need to act today to seed tomorrow's innovation ecosystem. Today's academics are the key to bootstrapping this, and government policies implemented through various funding mechanisms and management controls are the method by which this can be achieved. It is the assertion of this paper that the most direct way to achieve these collective objectives is to encourage industry and academic collaboration and commercialization by changing the incentives and barriers that currently limit their interaction. To achieve this outcome the following recommendations are made ${ }^{33}$ :

1. Change the ERA and ARC's grant awarding and assessment criteria to include measures of commercialization and industry impact for academic career advancement. Whilst these are in practice non-trivial to achieve it is crucial.

2. Require publically funded research to set aside a portion of such funds for capturing IP related to inventions generated in the research. Include metrics for invention disclosure/IP protection capture in the ARC/ERA metrics.

3. Furthermore since that research is publically funded consider mechanisms for requiring that the IP/patents so generated be licensed nonexclusively to "National enterprises" with net zero licensing fees/royalties. Universities should remain free to derive any licensing/royalty fees possible from overseas entities.

4. Encourage (perhaps require) interdisciplinary research and industry collaboration on academic grant funding applications. There are successful overseas examples implementing such arrangements that can act as model for this.

5. Incentivize companies to innovate - the present $45 \% \mathrm{R} \& \mathrm{D}$ tax rebate is a significant program that does help. Continue the program / expand as appropriate.

6. Incentivize companies to collaborate - consider R\&D tax incentive schedules that might further incentivize collaborative effort, especially with academia.

7. Stabilize the government innovation support programs for industry. Refinement and tweaks are good - it is the wholesale disbanding and or significant restructuring on a frequent basis that seriously undermines the

\footnotetext{
33 Cerneaz Nick. Australia's Innovation System. URL: https://thewarrencentre.org.au/wpcontent/uploads/2014/08/wc2662-1hr-SenateInnovationSystemInquiry.pdf
} 
innovation eco-system. Deliver the funds supporting innovation programs through an independent fund administered by an independent board.

8. Support the Chief Scientist's call for a National STEM strategy for our schools. Country needs significantly deeper Encourage a broader understanding of the full suite of STEM subjects across the community promote deeper technology and engineering literacy across the community. Country needs a nationally coordinated STEM strategy for primary and secondary schooling.

\section{SUMMARY}

The article has been dedicated to the problems of innovative development of Ukrainian economy. It was determined that international experiences in those sphere are useful for implement innovative instruments to create economy of knowledge in Ukraine. We need a system that encourages innovative products outcome. So we need a much bigger pool of companies that will collaborate with academic and university scientists. Today's they can/should be incentivized to form new enterprises/start-ups including: to exploit and commercialize their own existing and future inventions, to cross over into commercialization, create a new pool of innovations that can and are willing to engage in collaborative effort with academia and universities. And most significantly, to expand the number of local enterprises with positive collaboration experiences that will share their stories and encourage in others (their peers) a willingness to engage in collaborative efforts with science. To kick-start a vibrant local innovation national ecosystem, with government leadership on this score need to boot-strap a new cohort of (young) companies that are enthusiastic about innovation and engaging with the intellectual power resources available, and government policies implemented through various funding mechanisms and management controls are the method by which this can be achieved.

\section{REFERENCES}

1. Zimmermann V. An international comparison of R\&D: Germany benefits from industrial research strength", KFW research, No. 105, 25 August 2015. 
2. Richard R. Nelson. National Innovation Systems: A Comparative Analysis 1st Edition / Richard R. Nelson. Oxford University Press; 1 edition, 1993. $560 \mathrm{p}$.

3. Auerswald Philip E. Valleys of Death and Darwinian Seas: Financing the Invention to Innovation Transition in the United States / Philip E. Auerswald and Lewis M. Branscomb. The Journal of Technology Transfer. August 2003, Volume 28, Issue 3-4, pp. 227-239.

4. Nelson Richard R. National Innovation Systems: A Retrospective on a Study. Industrial and Corporate Change. 1992 January, 1(2), 347-374.

5. Крюков Л.М. Национальная инновационная система: проблемы становления и развития. Белорусский экономический журнал. 2003. № 4. С. 66-75.

6. Кузык Б.Н., Яковец Ю.В. Россия-2050: стратегия инновационного прорыва. 2-е изд. Москва, 2005. 440 с.

7. Иванова Н.И. Национальные инновационные системы. Москва, 2002. С. 86-87.

8. Семиноженко В.П. Інноваційна політика України як національний проект. Економіка знань: виклики глобалізащії та Україна / Під заг. ред. А.С. Гальчинського, С.В. Льовочкіна, В.П. Семиноженка. Київ, 2004. С. 18-39.

9. Потемкин А. Виртуальная экономика. Москва, 2004. С. 27.

10. Мясникович М.В. Роль науки в инновационной деятельности Беларуси. Инновационная политика государства и пути ее реализации : Материалы семинара. Мн., 2004. С. 81-96.

11. Малицький Б.А. Перепони інноваційного розвитку економіки та шляхи їх подолання. Утвердження інноваџійної моделі розвитку економіки Украӥни. Матер. наук.-практ. конф. Київ, 2003. С. 160-165.

12. Інноваційний розвиток економіки: модель, система управління, державна політика / За ред. Л.І. Федулової. Київ, 2005. C. 31-32.

13. Щербин В.К. Типологические отличия инновационной экономики. URL: http://iee.org.ua/files/alushta/66-scherbin-tipologi4eskie_ otli4iya.pdf (18.01.2012).

14. Rogers E. M. Diffusion of Innovations / Rogers E. M. - 3rd ed, The Free Press. - New York, NY, 1983. P. 11.

15. Barnett, H.G. (1953). Innovation, the Basis for Cultural Change. New York: Mc Graw Hil. 
16. Schumpeter J. The Theory of Economic Development. Harvard University Press, Cambridge, 1934.

17. Ruttan, V.W. and Hayami, Y. (1984) Toward a Theory of Induced Institutional Innovation. Journal of Development Studies, 20, 203-223.

18. Alainde Janvry, Elisabeth Sadoule. A study in resistance to institutional change: The lost game of Latin American land reform. World Development. 1989. Volume 17, Issue 9, September. P. 1397-1407.

19. Ruttan, V.W. and Hayami, Y. (1984) Toward a Theory of Induced Institutional Innovation. Journal of Development Studies, 20. P. 203-223.

20. Innovation Theory: A review of the literature ICEPT Working Paper May 2012.

21. Berglund Henrik. Interesting Theories of Innovation: the Practical use of the Particular / Henrik Berglund. Department of Innovation Engineering and Management Chalmers University of technology. 2004. WP \# 2004:1- 22 p.

22. The U.S. National Innovation System: Recent Developments in Structure and Knowledge Flows David C. Mowery/ Haas School of Business, University of California, Berkeley and Canadian Institute for Advanced Research, 1996.

23. Wessner Charles W. Rising to the Challenge: U.S. Innovation Policy for Global Economy Committee on Comparative National Innovation Policies: Best Practice for the 21st Century. Board on Science, Technology, and Economic Policy, Policy and Global Affairs / Charles W. Wessner, Wolff, Editor. National Academy of Sciences, 1212.

24. NASSCOM, "Indian IT-BPO Industry," 2011. URL: http://www.nasscom.in/indian-itbpo-industry

25. National Innovation Council, Towards a More Inclusive and Innovative India, September 2010. URL: http://www.innovationcouncil.gov.in/ downloads/NInC_english.pdf

26. National Academy of Sciences, S\&T Strategies of Six Countries, op. cit., p. 43.

27.27.Innovation Policies for the 21st Century: Report of a Symposium, Charles W. Wessner, editor, Washington, DC: The National Academies Press, 2007.

28. Gupta David W Nayanee. Innovation Policies of South Korea / Nayanee Gupta David W. Healey Aliza M. Stein Stephanie S. Shipp. Institute for defense analyses, 2013. - IDA Document D-4984. 71 p. 
29. Bishop W. The Elements of Leadership in a Global Environment. URL: https://onlinelibrary.wiley.com/doi/abs/10.1002/joe.21505

30. Mahlich Jorg. Korean Science and Technology in an International Perspective / Mahlich Jorg, Pascha Werner. Physica-Verlag Heidelberg, 2012. $288 \mathrm{p}$.

31. Negri Fernanda De Negri, Innovation policies in Brazil during the 2000s: the need for new paths / Fernanda De Negri, Andre Tortato Rauen. Institute for Applied Economic Research - ipea 2018. 60 p.

32. Cerneaz Nick. Australia's Innovation System. URL: https://thewarrencentre.org.au/wp-content/uploads/2014/08/wc2662-1hrSenateInnovationSystemInquiry.pdf

\section{Information about the authors: \\ Shostak L. B.}

Doctor of Economic Sciences,

Professor at the Department of Economy, Entrepreneurship and Natural Resources, Taurida National V. I. Vernadsky University, Ukraine

Dikarev O. I.

Candidate of Political Sciences, Associate Professor of the Chair of International Studies in Journalism, Kyiv National University of Culture and Art, Ukraine 